\title{
A FUZZY AHP MODEL TO ASSESS SUSTAINABLE PERFORMANCE OF THE CONSTRUCTION INDUSTRY FROM URBAN REGENERATION PERSPECTIVE
}

\author{
Zeynep IŞIK, Hande ALADAĞ \\ Department of Civil Engineering, Ylldı Technical University, Davutpaşa Caddesi, 34220 İstanbul, Turkey
}

Received 18 Feb 2016; accepted 26 Apr 2016

\begin{abstract}
The construction industry needs to assess its performance in the long term, considering the intangible parameters together with the tangible ones. Urban regeneration as well as infrastructural development have considerable impacts on the construction industry performance in developing countries. Therefore, in order to provide efficient and sustainable performance for the construction industry in the long term, it is crucial to determine the benchmarks and indicators from the perspective of those projects. In this context, major objective of this study is to represent a model showing the parameters affecting the sustainable performance of construction industry from urban regeneration perspective. Fuzzy Analytic Hierarchy Process (FAHP) analysis was employed in order to determine measures and indicators associated with sustainable performance and a model was established reaching the objective of the study. According to the FAHP analysis results, among measures such as Company Performance, Extrinsic, Economic, Environmental, Social and Innovational Factors set in the research, intangible values such as innovation and social protection were also found to have prior effects as well as the inevitable tangible ones such as cost, profitability and macro economy to sustain the performance of the construction industry for urban regeneration projects in the long term.
\end{abstract}

Keywords: performance measurement, sustainable performance, urban regeneration, construction industry, multi-criteria decision making, fuzzy logic, Fuzzy Analytic Hierarchy Process (FAHP).

\section{Introduction}

The sustainable success of the construction industry has been one of the most influential components of a country's economic growth. The indicators of success in construction industry were conventionally identified with some tangible factors such as turnover, profit, etc. (Love, Holt 2000). However, during the last decades, the outputs of the researches on performance indicated that consideration of intangible factors such as customer satisfaction, learning, etc. fundamentally provide sustainable success and eliminate the low performance and inefficiency of construction industry. The contemporary performance models including those measures and indicators helped to see the current situation, understand the drawbacks, predict opportunities and plan long-term strategic goals (Bassioni et al. 2004; Luu et al. 2008). The project-based nature of construction industry led us to consider construction companies and the projects as the main components of the industry. Therefore, with an inductive approach, it can be assumed that, project performance has effects on the individual companies' performance leading to effect the overall performance of the construction industry. This inductive approach points out the fact that, the long term contributions and causes of the projects that are mainly held by the construction companies within the industry should be well examined and selected so that long-term predictions regarding the industry would be acquired.

In developing countries where construction industry is considered as one of the main drivers of macro economy, governmental promotions as well as legal requirements lead companies to invest more on new construction projects in real estate sector. However, strategies in order to improve macro economy with a construction industry based approach had their own consequences such as increases in the volume of mortgages and inflation of the building stocks which in turn would cause to damage in the sustainable goals of the industry. There are a number of studies in the literature considering the performance measurement of construction industry (Love, Holt 2000; Cox et al. 2003), performance of construction companies (Bassioni et al. 2004; Luu et al. 2008) and the performance measurement of construction projects (Sarshar et al. 2004; Angus et al. 2005; Kim et al. 2009; Yang et al. 2009; Almahmoud et al. 2012). Another group of studies focus on sustainable performance of real estate

Corresponding author: Zeynep Işik

E-mail: zeynep@yildiz.edu.tr 
and urban regeneration projects (Hemphill et al. 2004b; Langstraat 2006; Chan, Lee 2008; Hunt et al. 2008; Shen et al. 2011; Michael et al. 2013). For example, Hemphill et al. (2004) evaluated the use of indicators as a means of measuring the performance of regeneration against sustainability criteria. Langstraat (2006) investigated the definitions of sustainability and degrees of success being applied to urban regeneration projects in Britain by using Hemphill's framework, which was found to effectively assess the sustainable performance of regeneration projects. Chan and Lee (2008) identified critical factors for enhancing social sustainability of urban regeneration projects. Hunt et al. (2008) discussed the role of indicators in achieving a more sustainable development as a part of the decision making process. Shen et al. (2011) identified environmental, economic and social factors with a set of 32 indicators. Michael et al. (2013) produced a list of sustainability indicators and used analytical hierarchy process to rank and prioritize urban sustainability indicators.

Given this brief background, it was hypothesized in this research that the sustainable performance of the construction industry can be indicated by the factors regarding company performance, extrinsic, economic, environmental, social and innovation factors in the life cycle of urban regeneration projects. Thus, the objective of the research was formed to determine suitable factors in the construction industry from urban regeneration perspective to develop a performance model. In this respect, a comprehensive literature review has been conducted to determine and compile those factors mentioned in the hypothesis. Then a brainstorming workshop was organized bringing together the expert stakeholders of urban regeneration projects in construction industry (industrial representatives, academics, construction companies, public institutions, non-governmental organizations, and urban regeneration specialists). In the workshop, determined factors that are indicated the sustainable performance of the construction industry regarding the proposed model were discussed from the urban regeneration perspective and evaluated in order to provide data for FAHP. The collected data were analyzed using FAHP to observe the perceptions of the stakeholders in terms of sustainable performance of construction industry from urban regeneration perspective. The findings of the research are expected to guide and give a perspective to construction professionals as well as the public entities on factors affecting sustainable performance of the construction industry.

\section{Factors affecting the sustainable performance of the construction industry}

Companies in the construction industry should evaluate their environmental, economic, and social contributions as well as their innovation and R\&D skills in order to achieve the goal of attaining a sustainable structure (OECD 2009). For this study, the balanced scorecard developed by Kaplan and Norton (1992) was used as a baseline to indicate company performance. Integrating sustainability perspective into a single and overarching strategic management tool was considered to overcome the shortcomings of conventional approaches to environmental and social management issues (Figge et al. 2002). Therefore in this study, indicated factors that are obtained from literature review are shown in Table 1.

\section{Research methodology and data collection}

In this study, a FAHP model has been employed to determine the importance of sustainable performance factors from urban regeneration perspective rather than determining the relationship between each main criteria. FAHP makes it possible to deal systematically with the kind of qualitative, imprecise information or even ill-structured decision problems. Despite the convenience of AHP in handling both quantitative and qualitative criteria of multi-criteria decision making problems based on decision maker's judgments, fuzziness and vagueness existing in many decision-making problems may contribute to the imprecise judgments of decision makers in conventional AHP approaches (Aggarwal, Singh 2013). Moreover, multilateral data collection is more practical compared to other methods since in such problems as urban regeneration, the stakeholders vary and needs to be intervened in order to have a joint resolution. The benefit of a fuzzy model is that it gives more practical results in the pairwise comparison process, deriving priorities from both consistent and inconsistent judgments and also creating an adequate reflection of the decision makers' attitude and their degree of confidence in the subjective assessments (Mikhailov, Singh 2003; Liu, Lai 2009; Yasmin et al. 2013). A review of the construction management literature reveals that a limited number of studies have been conducted combining both fuzzy set theory and AHP in performance management studies (Lee et al. 2008; Ertuğrul, Karakaşoğlu 2009; Sun 2010; Lee 2010; Aydogan 2011).

FAHP involves four steps. It starts with constructing the AHP model related with the problem structure and constructing pairwise matrices of the components with fuzzy judgments by using triangular fuzzy numbers. For these preliminary steps, a comprehensive literature review has been held and a number of 41 parameters were determined. Then, to refine the parameters, a pilot study was conducted by "three interviews" with an "urban regeneration specialist" in construction industry, "a professor from urban planning department" and a "professor from civil engineering department" and the final list of factors were reduced to 31 in this pilot study. Then, a group of "nine experts" was established to determine the interrelationships between the factors. Experts were selected among experienced stakeholders of urban regeneration who have worked on those kinds of projects throughout their careers. Commonly, there's no minimum number for the number of participants in AHP workshops, representation of the parties are assessed with their experiences and qualities rather than the numbers (Powell 2003; 
Table 1. Factors affecting the sustainable performance of the construction industry from urban regeneration perspective

\begin{tabular}{|c|c|c|}
\hline Main criteria & Sub-criteria & Reference \\
\hline \multirow{5}{*}{$\begin{array}{l}\text { Company } \\
\text { performance } \\
\text { factors }\end{array}$} & C1: Financial conditions & \multirow{5}{*}{$\begin{array}{l}\text { Balanced Scorecard; } \\
\text { Kaplan and Norton (1992) }\end{array}$} \\
\hline & C2: Internal business processes & \\
\hline & C3: Learning and growth & \\
\hline & C4: Client satisfaction/Stakeholder satisfaction & \\
\hline & C5: Employee satisfaction/Occupational health and safety & \\
\hline \multirow{6}{*}{$\begin{array}{l}\text { Extrinsic } \\
\text { factors }\end{array}$} & E1: Factor conditions & \multirow{6}{*}{$\begin{array}{l}\text { Porter's Diamond Model; } \\
\text { Porter (1990) }\end{array}$} \\
\hline & E2: Related and supporting corporations & \\
\hline & E3: Demand conditions & \\
\hline & E4: Legal legislation & \\
\hline & E5: Macro economy & \\
\hline & E6: Competition & \\
\hline \multirow[b]{3}{*}{$\begin{array}{l}\text { Economic } \\
\text { factors }\end{array}$} & Ec1: Project profitability & \multirow{3}{*}{$\begin{array}{l}\text { Cox et al. (2003); Hemphill et al. (2004); } \\
\text { Labuschagne et al. (2005); } \\
\text { Wang and Huang (2006); } \\
\text { Kim et al. (2009); Fernández-Sánchez and } \\
\text { Rodríguez-López (2010) }\end{array}$} \\
\hline & Ec2: Long term contribution of the project to industry & \\
\hline & Ec3: Long term contribution of the project to company & \\
\hline \multirow{7}{*}{$\begin{array}{l}\text { Environmental } \\
\text { factors }\end{array}$} & En1: Sustainable design & \multirow{7}{*}{$\begin{array}{l}\text { Hemphill et al. (2004); } \\
\text { Labuschagne et al. (2005); } \\
\text { Langstraat (2006); } \\
\text { Da Silva and Ruwanpura (2009); Fernández- } \\
\text { Sánchez and Rodríguez-López (2010); Shen } \\
\text { et al. (2011); } \\
\text { Michael et al. (2013) }\end{array}$} \\
\hline & En2: Land use & \\
\hline & En3: Waste management & \\
\hline & En4: Energy use & \\
\hline & En5: Use of materials & \\
\hline & En6: $\mathrm{CO}_{2}$ emission of the building & \\
\hline & En7: Environmental contribution of the project & \\
\hline \multirow{5}{*}{$\begin{array}{l}\text { Social } \\
\text { factors }\end{array}$} & S1: Protection of the cultural identity & \multirow{5}{*}{$\begin{array}{l}\text { Hemphill et al. (2004); Chan and Lee (2008); } \\
\text { Fernández-Sánchez and Rodríguez-López } \\
\text { (2010); Shen et al. (2011); Michael et al. } \\
\text { (2013) }\end{array}$} \\
\hline & S2: Protection of the architectural texture & \\
\hline & S3: Public security & \\
\hline & S4: Public satisfaction & \\
\hline & S5: Social contribution of the project & \\
\hline \multirow{5}{*}{$\begin{array}{l}\text { Innovation } \\
\text { factors }\end{array}$} & In1: Innovation in design & \multirow{5}{*}{ Ahmad et al. (1995); Arditi et al. (1997) } \\
\hline & In2: Innovation in material & \\
\hline & In3: Innovation in construction technology & \\
\hline & In4: Innovation in operational process & \\
\hline & In5: IT use in construction (BIM, ERP, etc.) & \\
\hline
\end{tabular}

Dikmen et al. 2010). Among the respondents were: 1) Industrial representatives: a project manager with a 17 years of experience in real estate and urban regeneration with a civil engineering background, a large-size construction contracting company owner with an experience of 25 years; 2) Academics: a professor from urban planning department, a professor from civil engineering department; 3) Public Institutions: a director of urban planning department in a local municipality with 16 years of experience, a representative of urban regeneration department of metropolitan municipality with 10 years of experience; 4) Non-governmental organizations: a representative of chamber of civil engineers; and 5) Urban Regeneration Specialists: two urban regeneration specialists with architectural backgrounds experienced in real estate and urban regeneration for 15 and 20 years, respectively. In the brainstorming session, the experts stated their opinions about the factors indicating the performance of construction industry from urban regeneration perspective responding to the pairwise matrices of the components with fuzzy judgments by using triangular fuzzy numbers. Ultimately, the consensual fuzzy judgments representing all the stakeholders' opinion were used as final data.

\section{Analyses and related comments}

This section presents the application steps of fuzzy AHP and the analysis results related to each step is exemplified over one criterion. The general steps of fuzzy AHP and their application in this study are presented as follows.

Step 1. Model construction and problem structuring: the factors affecting the sustainable performance of the construction industry in terms of urban regeneration projects determined based on a literature study were refined with a pilot survey reducing the number of parameters to a number of 31 from the initial list of 41 parameters. An AHP model structure has been configured that includes criteria and sub-criteria among factors affecting the sustainable performance. In this context, the formed AHP model structure is shown in Figure 1. 


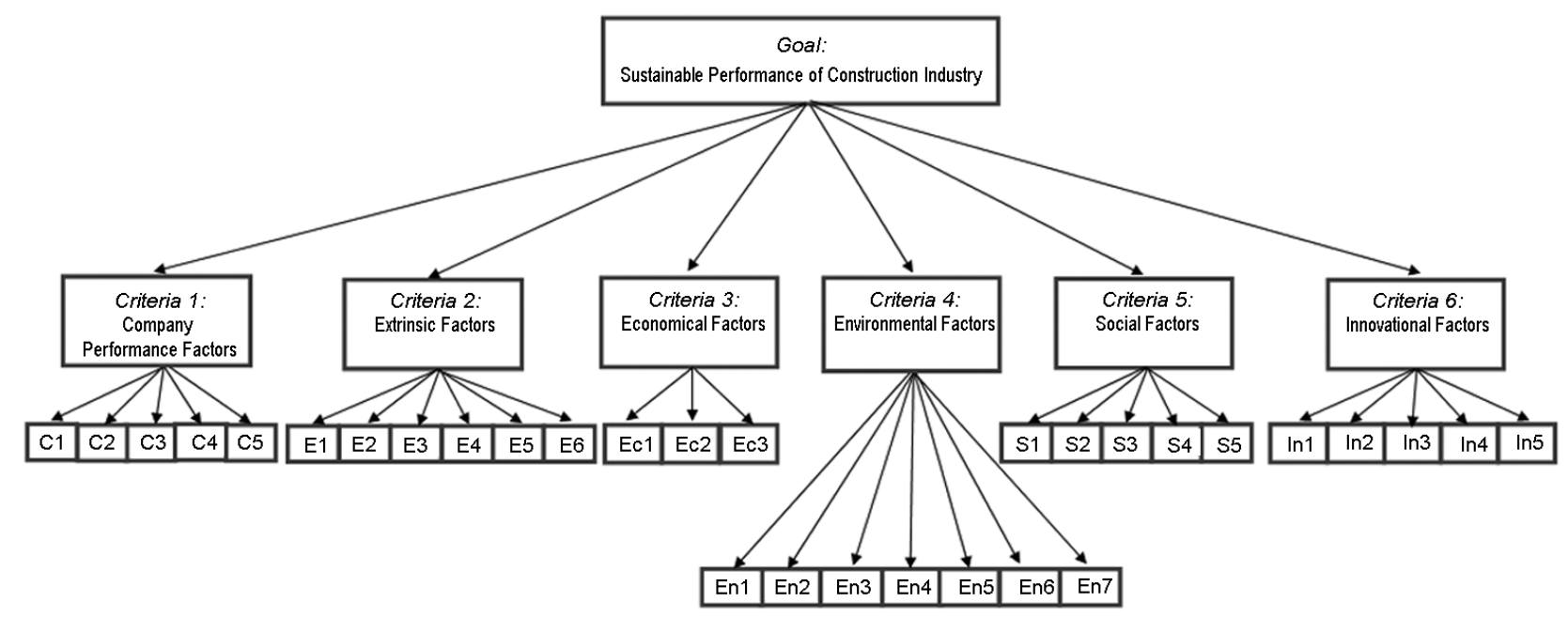

Fig. 1. AHP model structure

Step 2. Construct pairwise matrices of the components with fuzzy judgments by using triangular fuzzy numbers: the experts were asked to make pairwise comparisons between determined indicators and measures. A triangular fuzzy number was defined with three parameters as $(l$, $m, u$ ) where, respectively, "l" denotes the smallest possible value, " $m$ " denotes the most promising value, and " $u$ " denotes the largest possible value to describe a fuzzy event. In order to determine the relative preferences for two elements in fuzzy AHP-matrix, Triangle Fuzzy Scale (Table 2) was used.

Table 2. Triangle fuzzy scale (Chang 1996)

\begin{tabular}{l|c|c|c}
\hline $\begin{array}{c}\text { Preferences } \\
\text { expressed in } \\
\text { linguistic variables }\end{array}$ & $\begin{array}{c}\text { Numeric } \\
\text { variables }\end{array}$ & $\begin{array}{c}\text { Triangle } \\
\text { fuzzy scale }\end{array}$ & $\begin{array}{c}\text { Triangle fuzzy } \\
\text { reciprocal } \\
\text { scale }\end{array}$ \\
\hline Just Equal & 1 & $(1,1,1)$ & $(1,1,1)$ \\
\hline $\begin{array}{l}\text { Equally Important/ } \\
\text { preferred }\end{array}$ & 2 & $(1 / 2,1,3 / 2)$ & $(2 / 3,1,2)$ \\
\hline $\begin{array}{l}\text { Weakly Important/ } \\
\text { preferred }\end{array}$ & 3 & $(1,3 / 2,2)$ & $(1 / 2,2 / 3,1)$ \\
\hline $\begin{array}{l}\text { Strongly More } \\
\text { Important/preferred }\end{array}$ & 4 & $(3 / 2,2,5 / 2)$ & $(2 / 5,1 / 2,2 / 3)$ \\
\hline $\begin{array}{l}\text { Very Strongly More } \\
\text { Important/preferred }\end{array}$ & 5 & $(2,5 / 2,3)$ & $(1 / 3,2 / 5,1 / 2)$ \\
\hline $\begin{array}{l}\text { Absolutely More } \\
\text { Important/preferred }\end{array}$ & 6 & $(5 / 2,3,7 / 2)$ & $(2 / 7,1 / 3,2 / 5)$ \\
\hline
\end{tabular}

The experts filled the pairwise matrices in terms of $i$. Pairwise comparisons of main criteria according to the goal, ii. Cluster comparison of sub-criteria with respect to belonging criteria (indicators). The pairwise comparisons of criteria with related to goal with fuzzy numbers is shown in the Table 3 as an example.

Step 3: Chang's extent analysis method: After the pairwise comparison matrix was obtained using fuzzy numbers, Chang's extent analysis method was used to eliminate uncertainty. Chang's $(1992,1996)$ extent analysis provides a general method of using crisp mathematical concepts to address fuzzy quantities. Let $X=\left(x_{1}, x_{2}, x_{3}\right.$, $\left.\ldots, x_{n}\right)$ be an object set and $U=\left(u_{1}, u_{2}, u_{3}, \ldots, u_{m}\right)$ be a goal set. According to Chang's extent analysis method, each object is taken and extent analysis for each goal, $g_{i}$ is performed, respectively. First, the value of fuzzy synthetic extent is calculated by using the Eqns (1) to (4):

$$
\begin{aligned}
& S_{i}=\sum_{j=1}^{m} M_{g i}^{j} x\left[\sum_{j=1}^{n} \sum_{j=1}^{m} M_{g i}^{j}\right]^{-1} ; \\
& \sum_{j=1}^{m} M_{g i}^{j}=\left(\sum_{j}^{m} l_{j}, \sum_{j=1}^{m} m_{j}, \sum_{j=1}^{m} u_{j}\right)
\end{aligned}
$$

Table 3. The pairwise comparisons of criteria with related to goal with fuzzy numbers

\begin{tabular}{l|l|l|l|lll}
\hline & \multicolumn{1}{|c|}{$\mathrm{Cr} 1$} & \multicolumn{1}{c}{$\mathrm{Cr} 2$} & \multicolumn{1}{c}{$\mathrm{Cr} 3$} & \multicolumn{1}{c}{$\mathrm{Cr} 4$} & \multicolumn{1}{c}{$\mathrm{Cr} 5$} & $\mathrm{Cr}$ \\
\hline $\mathrm{Cr} 1$ & $(1,1,1)$ & $(2 / 5,1 / 2,2 / 3)$ & $(1,3 / 2,2)$ & $(1 / 3,2 / 5,1 / 2)$ & $(2 / 5,1 / 2,2 / 3)$ & $(1 / 3,2 / 5,1 / 2)$ \\
\hline $\mathrm{Cr} 2$ & $(3 / 2,2,5 / 2)$ & $(1,1,1)$ & $(1,3 / 2,2)$ & $(1 / 2,2 / 3,1)$ & $(2 / 5,1 / 2,2 / 3)$ & $(1 / 2,2 / 3,1)$ \\
\hline $\mathrm{Cr} 3$ & $(1 / 2,2 / 3,1)$ & $(1 / 2,2 / 3,1)$ & $(1,1,1)$ & $(1 / 2,2 / 3,1)$ & $(2 / 5,1 / 2,2 / 3)$ & $(1 / 2,1,3 / 2)$ \\
\hline $\mathrm{Cr} 4$ & $(2,5 / 2,3)$ & $(1,3 / 2,2)$ & $(1,3 / 2,2)$ & $(1,1,1)$ & $(1,3 / 2,2)$ & $(3 / 2,2,5 / 2)$ \\
\hline $\mathrm{Cr} 5$ & $(3 / 2,2,5 / 2)$ & $(3 / 2,2,5 / 2)$ & $(3 / 2,2,5 / 2)$ & $(1 / 2,2 / 3,1)$ & $(1,1,1)$ & $(3 / 2,2,5 / 2)$ \\
\hline Cr6 & $(2,5 / 2,3)$ & $(1,3 / 2,2)$ & $(2 / 3,1,2)$ & $(2 / 5,1 / 2,2 / 3)$ & $(2 / 5,1 / 2,2 / 3)$ & $(1,1,1)$ \\
\hline
\end{tabular}


and obtain $\left[\sum_{j=1}^{n} \sum_{j=1}^{m} M_{g i}^{j}\right]^{-1}$ perform the fuzzy addition operation of $M_{g i}^{j}(\mathrm{j}=1,2, \ldots, \mathrm{m})$ values such that:

$$
\left[\sum_{j=1}^{n} \sum_{j=1}^{m} M_{g i}^{j}\right]=\left(\sum_{j}^{m} l_{j}, \sum_{j=1}^{m} m_{j}, \sum_{j=1}^{m} u_{j}\right)
$$

and then compute the inverse of the vector in Eqn (4) such that:

$$
\left[\sum_{j=1}^{n} \sum_{j=1}^{m} M_{g i}^{j}\right]^{-1}=\left(\frac{1}{\sum_{j=1}^{n} u_{i}}, \frac{1}{\sum_{j=1}^{n} u m_{i}}, \frac{1}{\sum_{j=1}^{n} l_{i}}\right) .
$$

The value of fuzzy synthetic extent for the pairwise comparisons of criteria with related to goal is calculated by using the Eqns (1) to (4) and the results are shown in the Table 4 as an example.

Table 4. The value of fuzzy synthetic extent for the pairwise comparisons of criteria with related to goal

\begin{tabular}{c|c|c|c}
\hline & $L$ & $M$ & $U$ \\
\hline$S_{1}$ & 0.065 & 0.103 & 0.165 \\
\hline$S_{2}$ & 0.092 & 0.152 & 0.253 \\
\hline$S_{3}$ & 0.064 & 0.108 & 0.191 \\
\hline$S_{4}$ & 0.140 & 0.239 & 0.388 \\
\hline$S_{5}$ & 0.140 & 0.231 & 0.372 \\
\hline$S_{6}$ & 0.102 & 0.167 & 0.290 \\
\hline
\end{tabular}

Then, degree of possibility was obtained using the value of fuzzy synthetic extent. Probability values were calculated using using Eqns (5) to (7). Here, the possibility of choosing one criterion out of the other criterion was obtained. The weights vector was then obtained with the help of the possibilities. The normalized weights vector was used to select the best alternative. The degree of possibility of $M_{2}=\left(l_{2}, m_{2}, u_{2}\right) \geq M_{1}=\left(l_{1}, m_{1}, u_{1}\right)$ is defined as:

$$
V\left(M_{1} \geq M_{2}\right)=\sup \left[\min \left(\mu_{M 1}(x), \mu_{M 2}(y)\right)\right] .
$$

When a pair $(x, y)$ exists such that $x \geq y$ and $\mu_{M 1}(x)=$ $\mu_{M 2}(y)=1$, then we have $V\left(M_{1} \geq M_{2}\right)=1$. Since $M_{1}$ and $M_{2}$ are convex fuzzy numbers we have that:

$$
V\left(M_{1} \geq M_{2}\right)=1 \text {, if } m_{1} \geq m_{2} ;
$$

$V\left(M_{2} \geq M_{1}\right)=\operatorname{hgt} M_{1} \cap M_{2}=\mu_{M 2}$, where: $d$ is the ordinate of the highest intersection point $D$ between $\mu_{M 1}$ and $\mu_{M 2}$. When $M_{1}=\left(l_{1}, m_{1}, u_{1}\right)$ and $M_{2}=\left(l_{2}, m_{2}, u_{2}\right)$, the ordinate of $D$ is given by Eqn (7):

$$
V\left(M_{2} \geq M_{1}\right)=\operatorname{hgt} M_{1} \cap M_{2}=\frac{l 1-u 2}{(m 2-u 2)-(m 1-l 1)} .
$$

To compare $M_{1}$ and $M_{2}$, we need both the values of $V=\left(M_{1} \geq M_{2}\right)$ and $V=\left(M_{2} \geq M_{1}\right)$.

The degree possibility for convex fuzzy numbers for the pairwise comparisons criteria with related to goal is calculated by using the Eqns (5) to (7) and the results are shown in the Table 5 as an example.

The degree possibility for a convex fuzzy number to be greater than $k$ convex fuzzy numbers, $M_{i}(1,2, \ldots, k)$ can be defined by Eqn (8):

$$
\begin{gathered}
V\left(M \geq M_{1}, M_{2}, \ldots, M_{k}\right)=V\left[\left(M \geq M_{1}\right)\right. \text { and } \\
\left(M \geq M_{2}\right) \quad \text { and...and } \\
\left.\left(M \geq M_{k}\right)\right]=\min V\left(M \geq M_{i}\right) ; \\
i=1,2, \ldots, k .
\end{gathered}
$$

Assume that $d^{\prime}\left(A_{i}\right)=\min V\left(S_{i} \geq S_{k}\right)$ for $=1,2, \ldots$, $n ; k \neq i$. Then the weight vector $(W)$ is given by Eqn (9):

$$
W^{\prime}=\left(d^{\prime}\left(A_{1}\right),\left(A_{2}\right), \ldots, d^{\prime}\left(A_{n}\right)\right)^{T},
$$

where: $A_{i}(i=1,2, \ldots, n)$ are $\mathrm{n}$ elements.

Via normalization, the normalized weight vectors where $W$ is a non-fuzzy number - were calculated using the Eqn (10):

$$
W=\left(d\left(A_{1}\right), d\left(A_{2}\right), \ldots, d\left(A_{n}\right)\right)^{T} .
$$

The minimum degree of possibility for the example

\begin{tabular}{|c|c|c|c|c|c|c|c|c|c|c|c|}
\hline$V\left(S_{1}>S_{2}\right)$ & 0.603 & $V\left(S_{2}>S_{1}\right)$ & 1 & $V\left(S_{3}>S_{1}\right)$ & 1 & $V\left(S_{4}>S_{1}\right)$ & 1 & $V\left(S_{5}>S_{1}\right)$ & 1 & $V\left(S_{6}>S_{1}\right)$ & 1 \\
\hline$V\left(S_{1}>S_{3}\right)$ & 0.955 & $V\left(S_{2}>S_{3}\right)$ & 1 & $V\left(S_{3}>S_{2}\right)$ & 0.695 & $V\left(S_{4}>S_{2}\right)$ & 1 & $V\left(S_{5}>S_{2}\right)$ & 1 & $V\left(S_{6}>S_{2}\right)$ & 1 \\
\hline$V\left(S_{1}>S_{4}\right)$ & 0.156 & $V\left(S_{2}>S_{4}\right)$ & 0.563 & $V\left(S_{3}>S_{4}\right)$ & 0.280 & $V\left(S_{4}>S_{3}\right)$ & 1 & $V\left(S_{5}>S_{3}\right)$ & 1 & $V\left(S_{6}>S_{3}\right)$ & 1 \\
\hline$V\left(S_{1}>S_{5}\right)$ & 0.164 & $V\left(S_{2}>S_{5}\right)$ & 0.587 & $V\left(S_{3}>S_{5}\right)$ & 0.293 & $V\left(S_{4}>S_{5}\right)$ & 1 & $V\left(S_{5}>S_{4}\right)$ & 0.967 & $V\left(S_{6}>S_{4}\right)$ & 0.675 \\
\hline$V\left(S_{1}>S_{6}\right)$ & 0.495 & $V\left(S_{2}>S_{6}\right)$ & 0.905 & $V\left(S_{3}>S_{6}\right)$ & 0.598 & $V\left(S_{4}>S_{6}\right)$ & 1 & $V\left(S_{5}>S_{6}\right)$ & 1 & $V\left(S_{6}>S_{5}\right)$ & 0.701 \\
\hline
\end{tabular}
of the pairwise comparisons of criteria with related to goal is calculated by using the Eqns (8) to (10) and the results are shown in the Table 6 as an example.

Step 4: Calculate fuzzy Eigen Value: after the pairwise comparison matrix was obtained and Chang's extent analysis method was used to eliminate uncertainty, Eigen Value was calculated to find whether the constructed matrix was consistent or not. Saaty (1980) proposed a consistency index (C.I.) and consistency ratio (C.R.) to verify the consistency

Table 5. The degree possibility for convex fuzzy numbers for the pairwise comparisons criteria with related to goal 
Table 6. The minimum degree of possibility for the example of the pairwise comparisons of criteria with related to goal

\begin{tabular}{c|l}
\hline \multicolumn{1}{c|}{$\left(A_{1}\right)$} & $V\left(S_{1} \geq S_{2}, S_{3}, S_{4}, S_{5}, S_{6}\right)=\min (0.603,0.955,0.156,0.164,0.495)=0.156$ \\
\hline$d^{\prime}\left(A_{2}\right)$ & $V\left(S_{2} \geq S_{1}, S_{3}, S_{4}, S_{5}, S_{6}\right)=\min (1,1,0.563,0.587,0.905)=0.563$ \\
\hline$d^{\prime}\left(A_{3}\right)$ & $V\left(S_{3} \geq S_{1}, S_{2}, S_{4}, S_{5}, S_{6}\right)=\min (1,0.695,0.280,0.293,0.598)=0.280$ \\
\hline$d^{\prime}\left(A_{4}\right)$ & $V\left(S_{4} \geq S_{1}, S_{2}, S_{3}, S_{5}, S_{6}\right)=\min (1,1,1,1,1)=1$ \\
\hline$d^{\prime}\left(A_{5}\right)$ & $V\left(S_{5} \geq S_{1}, S_{2}, S_{3}, S_{4}, S_{6}\right)=\min (1,1,1,0.967,1)=0.967$ \\
\hline$d^{\prime}\left(A_{6}\right)$ & $V\left(S_{6} \geq S_{1}, S_{2}, S_{3}, S_{4}, S_{5}\right)=\min (1,1,1,0.675,0.701)=0.675$ \\
\hline $\begin{array}{l}\text { The weight vector } \\
\begin{array}{l}\text { via normalization the importance weights of the } \\
\text { main attributes }\end{array}\end{array}$ & $W=(0.156,0.563,0.280,1,0.967,0.675)^{T}$ \\
\hline
\end{tabular}

of the comparison matrix. The consistency index of a matrix is given by using Eqns (11) and (12):

$$
\begin{gathered}
\text { C.I. }=\left(\lambda_{\max }-n\right) /(n-1) ; \\
\text { C.R. }=\text { C.I. }(\text { Consistency Index }) / \\
\text { R.I. (Random Consistency Index }),
\end{gathered}
$$

where: $\lambda_{\max }$ is the largest Eigen value of the comparison matrix, $n$ is the dimension of the matrix, and $R I(n)$ is a random index, that depends on $n$, as shown in Table 7 .

Table 7. Consistency index, R.I., of random matrices (Golden et al. 1989)

\begin{tabular}{c|c|c|c|c|c|c|c}
\hline$n$ & 3 & 4 & 5 & 6 & 7 & 8 & 9 \\
\hline R.I. $(n)$ & 0.58 & 0.9 & 1.12 & 1.24 & 1.32 & 1.41 & 1.45 \\
\hline
\end{tabular}

On a scale from zero to one, the overall inconsistency should be around $10 \%$. Otherwise the judgments expressed by the experts are considered to be inconsistent (Büyüközkan, Çifçi 2012; Yasmin et al. 2013) and the decision maker has to repeat the pairwise comparison matrix in brainstorming session. A triangular fuzzy number, denoted as $M=(l, m, u)$, can be defuzzified to a crisp number by using Eqn (13) (Kwong, Bai 2003):

$$
M_{-} \text {crisp }=(4 m+l+n) / 6 .
$$

For the example of the pairwise comparisons of criteria with related to goal; consistency index is equal to 0.06 and consistency ratio is equal to $0.048(0.06 / 1.24)$. It can be indicated that $C . R$. is valid because the numerical value of the consistency index is less than 0.10 .

In this study, a fuzzy decision support system was developed by using Microsoft Excel for solving FAHP matrices. Microsoft Excel worksheets used Chang's Extent Analysis Method as the solving procedure. The initial configuration of matrices, the problem statement, input matrices, results of solved FAHP matrices, calculations about consistency ratio and weighted values $(W)$ were all done in Microsoft Excel workspace. In this context, the overall synthesized priorities of proposed FAHP structure were presented in Table 8 .

\section{Discussion}

The overall synthesized priorities according to the FAHP model analyses can be discussed as follows.

General assessment of the overall results: urban regeneration can be defined as a comprehensive expression of the strategies and actions that aim to enhance the economic, social, physical, and environmental conditions compatible with the main principles of sustainability (Parkinson 1989). The overall synthesized priorities showed that "Environmental factors" should be considered as a priority in order to sustain the performance of the construction industry. Thereafter, "Social factors" showed up as the second worthy of notice factor. "Innovational factors", "Extrinsic factors", "Economic factors" and "Company performance factors" have the least influence on the sustainable performance of the construction, respectively. In the performance management literature; it is seen that performance measurement efforts generally focus on the factors such as cost, production time and quality (Love, Holt 2000). However, the results of the study highlighted the contributions of these projects in environmental and social level.

Environmental factor cluster: in recent years, the concepts of sustainability and energy efficiency have gained greater emphasis in the construction industry. According to the synthesized priorities of "Environmental Factors"; "Environmental contribution of the project (En7)" with a weight of 0.236 has the highest ranking. Thereafter " $\mathrm{CO}_{2}$ emission of the building (En6)" with the weight of 0.221 comes in second place whereas "Use of material (En5)", "Waste management (En3)" and "Sustainable design (En1)" has the lowest ranking respectively. In the study, environmental contribution of the project refer to the interference with soil during construction and postconstruction stages, impact of the building on the water resources, creation of green areas and increased environmental quality.

Social factor cluster: according to the synthesized priorities of "Social Factors"; "Protection of the architectural texture (S2)" with a weight of 0.312 has the highest ranking. Thereafter "Public security (S3)" with the weight of 0.305 comes in second place whereas "Public 
Table 8 . The synthesized priorities of sustainability factors

\begin{tabular}{|c|c|c|c|}
\hline \multicolumn{4}{|c|}{ Factors Affecting Sustainable Performance } \\
\hline Main Criteria & $\begin{array}{c}\text { Normalized priorities } \\
\text { of alternatives }\end{array}$ & Sub-criteria & $\begin{array}{l}\text { Normalized priorities } \\
\text { of sub-criteria }\end{array}$ \\
\hline \multirow{5}{*}{$\begin{array}{l}\text { Company } \\
\text { Performance } \\
\text { Factors }\end{array}$} & \multirow{5}{*}{0.043} & C1: Financial conditions & 0.247 \\
\hline & & C2: Internal business processes & 0.051 \\
\hline & & C3: Learning and growth & 0.403 \\
\hline & & C4: Client satisfaction/Stakeholder satisfaction & 0.278 \\
\hline & & C5: Employee satisfaction /Occupational health and safety & 0.021 \\
\hline \multirow{6}{*}{$\begin{array}{l}\text { Extrinsic } \\
\text { Factors }\end{array}$} & \multirow{6}{*}{0.155} & E1: Factor conditions & 0.057 \\
\hline & & E2: Related and supporting corporations & 0.132 \\
\hline & & E3: Demand conditions & 0.114 \\
\hline & & E4: Legal legislation & 0.137 \\
\hline & & E5: Macro economy & 0.287 \\
\hline & & E6: Competition & 0.273 \\
\hline \multirow{3}{*}{$\begin{array}{l}\text { Economic } \\
\text { Factors }\end{array}$} & \multirow{3}{*}{0.077} & Ec1: Project profitability & 0.086 \\
\hline & & Ec2: Long term contribution of the project to industry & 0.457 \\
\hline & & Ec3: Long term contribution of the project to company & 0.457 \\
\hline \multirow{7}{*}{$\begin{array}{l}\text { Environmental } \\
\text { Factors }\end{array}$} & \multirow{7}{*}{0.275} & En1: Sustainable design & 0.023 \\
\hline & & En2: Land use & 0.199 \\
\hline & & En3: Waste management & 0.065 \\
\hline & & En4: Energy use & 0.160 \\
\hline & & En5: Use of materials & 0.096 \\
\hline & & En6: $\mathrm{CO} 2$ emission of the building & 0.221 \\
\hline & & En7: Environmental contribution of the project & 0.236 \\
\hline \multirow{5}{*}{$\begin{array}{l}\text { Social } \\
\text { Factors }\end{array}$} & \multirow{5}{*}{0.265} & S1: Protection of the cultural identity & 0.226 \\
\hline & & S2: Protection of the architectural texture & 0.312 \\
\hline & & S3: Public security & 0.305 \\
\hline & & S4: Public satisfaction & 0.009 \\
\hline & & S5: Social contribution of the project & 0.148 \\
\hline \multirow{5}{*}{$\begin{array}{l}\text { Innovation } \\
\text { Factors }\end{array}$} & \multirow{5}{*}{0.185} & In1: Innovation in design & 0.013 \\
\hline & & In2: Innovation in material & 0.254 \\
\hline & & In3: Innovation in construction technology & 0.220 \\
\hline & & In4: Innovation in operational process & 0.167 \\
\hline & & In5: IT use in construction & 0.346 \\
\hline
\end{tabular}

satisfaction (S4)" with a weight of 0.009 has the lowest ranking. Herein protection of landscape, historical sites and urban identity constitute the context of architectural texture production. Whether it is a historical city or not; cities should protect their own urban identity and culture while presenting healthy, livable spaces and creative opportunities for its citizens. Besides, shanty settlements caused by intensive urbanization not only destruct the texture and environment; they can also create unresolved social problems in terms of Public security (S3). In this context, crime rate will decline as a result of sociological changes in the areas where urban regeneration projects are implemented. In the FAHP analyses "Public satisfaction (S4)" has the lowest ranking indicating the reality in project implementations where the profit maximization is the first priority. However, in urban regeneration projects, public satisfaction defines practices that take into consideration community development and social justice, such as creating public space/urban center/attraction point/ social infrastructure; increasing quality of life; accessing health, education, housing and public services; and providing socio-economic balance and social integration, therefore "Public satisfaction" should be considered as an important factor in order to provide the construction industry success in the long term (Hemphill et al. 2004).

Innovation factor cluster: changing business conditions due to globalization, improved technology, transformed demands and needs of customers and etc. give 
rise to an increase in competition in construction industry. In this context, in order to survive and sustain in the long term, construction companies should progress in the field of technology and innovation. Thus, innovation approaches are of the essence in terms of competitiveness for the construction industry's success. According to this, among the determined "Innovation Factors"; the overall synthesized priorities show that "Information technology (IT) use in construction (In5)" with a weight of 0.346 has the highest ranking in terms of sustainable performance of construction industry. Thereafter "Innovation in material (In2)" with the weight of 0.254 comes in second place whereas "Innovation in design (In1)" with a weight of 0.013 has the lowest ranking. The purpose of IT is to facilitate the exchange and management of information and has a lot of potentials for the information process component of the construction industry with their profound impact on how organisations operate on a daily basis (Rivard 2000). On the other hand, urban regeneration is seen as an important driving force for the transition to energy-efficient and smart buildings. In order to achieve the performance criteria in the context of energy efficiency and carbon emissions, it is predicted that the demand for innovative construction and innovative construction materials will increase.

Extrinsic factor cluster: according to synthesized priorities of "Extrinsic Factors"; "Macro economy (E5)" with a weight of 0.287 has the highest ranking. Thereafter "Competition (E6)" with the weight of 0.273 is in second rank whereas "Factor conditions (E1)" has the lowest ranking with the weight of 0.057. Macro economy (E5) encompasses unearned income as an acquisition that is provided by increasing land prices due to urban regeneration projects; revitalization and development of economic activities within the scope of urban regeneration projects by creating or improving job opportunities, both qualitatively and quantitatively (Hemphill et al. 2004). Besides, the selection of contractor companies for regeneration projects increase the volume of competition between the companies where financial and technical capability emerge as the most important selection criteria. In this study, factor conditions, which can be listed as human resources, physical resources, knowledge resources, capital resources, and infrastructure ensue as the sub-criteria that have the lowest ranking in the cluster.

Economic factor cluster: despite the social and environmental contributions that urban regeneration projects have unlike other types of construction projects, financial performance is inevitable for the companies and industry both. According to the analysis of sub-criteria with respect to "Economic Factors"; "Long term contribution of the project to industry (Ec2)" and "Long term contribution of the project to company (Ec3)" with the weight of 0.457 have the highest ranking in cluster whereas "Project profitability (Ec1)" with the weight of 0.086 has the lowest ranking. Project profitability is important for selffinancing the project in the short term and also for cre- ating financial resources for probable future projects in the long term. But in this study, the comparative results of FAHP showed that long-term economic and financial contributions are more important than project profitability since sustainable construction industry performance was considered as the goal.

Company performance factor cluster: the project based nature of construction industry lead us to consider construction companies and the projects as the main components of the industry. Therefore, with an inductive approach, it can be assumed that, project performance has effects on the individual companies' performance leading to effect the overall performance of the construction industry. This inductive approach points out the fact that, the performance improvements in construction companies will directly affect the performance of the construction industry. According to the synthesized priorities of "Company Performance Factors"; "Learning and growth (C3)" with a weight of 0.403 has the highest ranking. Thereafter "Client satisfaction/Stakeholder satisfaction (C4)" with the weight of 0.278 comes in second place whereas "Employee satisfaction/Occupational health and safety (C5)" with a weight of 0.021 has the lowest ranking. In general, client/stakeholders in construction projects can be listed as; owner, employer, contractor, sub-contractors, end users and etc. However in urban regeneration projects, public institutions, non-governmental organizations, urban regeneration specialists and even the community who are going to be affected by the changes/transformations related with the regeneration project can be listed as stakeholders. Because of this reason, determination of the stakeholders that are going to be affected directly or indirectly by the project; creating an organizational model for the stakeholder management and managing stakeholders' expectations related to urban regeneration project are of vital importance.

\section{Conclusions}

Taking into consideration the internal and external parameters affecting the construction industry's performance, mega transportation, energy and urban regeneration projects are seen as an important potential with the considerable impact they have on the construction industry and also in terms of engineering and technical consultancy. In this context this study only focus on the urban regeneration perspective as part of an on-going research which aims to reveal factors affecting sustainable performance of construction industry with a holistic approach by also paying regard to mega transportation and energy perspective which have a considerable impact on the construction industry in developing countries along with urban regeneration.

Within the focus of the study, urban regeneration projects can be used as a strategic solution to balance the increase in housing supply in contrast to the decrease in housing demand in developing countries. It is crucial to determine the benchmarks and indicators to provide 
efficient and sustainable performance in the long term, considering the importance of the urban regeneration projects on the overall performance of the construction industry and national economy. Thus, factors affecting the sustainable performance of construction industry from urban regeneration perspective should be determined and analyzed correctly. By this way construction companies paying attention to those factors, can achieve success in the industry. In this context, this paper provides a clear insight on the factors affecting the sustainability of construction industry from urban regeneration perspective by establishing a FAHP model that represents hierarchy and related priorities between determined sustainable performance factors. The proposed FAHP model had six main criteria and a total of 31 sub-criteria that are related with the main criteria. After the hierarchy between these criteria and sub-criteria were determined, the analyses were established according to the applications of the extent analysis method on fuzzy AHP developed by Chang (1996). The FAHP model solves the ambiguity and imprecision of the pairwise comparison process substantially by using fuzzy numbers instead of assuming precise numbers as comparison values. Thus, using fuzzy structure as a multi-attribute decision making technique, relatively more sufficient decision making is obtained with the flexibility in the process of the comparisons that experts and decision makers have.

The results of the study show that environmental factors have a priority in sustaining the performance of the urban regeneration projects. A firm that pays special attention to integrating energy and environmental awareness into design and construction of urban regeneration projects can improve the quality of buildings and living areas, and can also reduce environmental impact by designing and building a healthy environment. Thus, it is important to have a planned approach in topics like environmental contribution of the project, $\mathrm{CO}_{2}$ emission, material use and etc. in order to affect the performance of urban regeneration projects. It is also a well-known fact that, urban regeneration projects are generally needed to transform old, unused, and dysfunctional industrial areas into useful, legal and healthy areas; or they are needed to transform residential district which has lost its economic, social or cultural importance into a useful area. The factors such as protection of the cultural identity and architectural texture, public security and public satisfaction are more important in urban regeneration projects as compared with other housing projects since the targets and the aims of the applications in urban regeneration are different from those in other construction projects. Thus, construction companies who play a part in urban regeneration projects should consider protection of urban identity and culture as a priority while presenting healthy, livable spaces and creative opportunities for citizens.

The research opens up to future developments such as developed model can be applied to different stakeholders separately, can be tested on urban regeneration projects/companies and the comparisons can be analyzed if there exist any different perception of stakeholders in the context of presented model. Also each set of performance factors gathered from three different pillars (urban regeneration, mega transportation and energy) affecting the sustainable performance of construction industry can be interrelated as a further step of mentioned ongoing research.

\section{Acknowledgements}

The work described in this paper was supported by Coordinatorship of Scientific Research Projects of Yıldız Technical University (Project Number: 2011-05-01-GEP01).

\section{References}

Aggarwal, R.; Singh, S. 2013. AHP and Extent Fuzzy AHP approach for prioritization of performance measurement attributes, International Journal of Mechanical, Aerospace, Industrial, Mechatronic and Manufacturing Engineering 7(1): 6-11.

Ahmad, I. U.; Russell, J. S.; Abou-Zeid, A. 1995. Information technology (IT) and integration in the construction industry, Construction Management and Economics 13(2): 163171. https://doi.org/10.1080/01446199500000018

Almahmoud, E. S.; Doloi, H. K.; Panuwatwanich, K. 2012. Linking project health to project performance indicators: multiple case studies of construction projects in Saudi Arabia, International Journal of Project Management 30(3): 296-307.

https://doi.org/10.1016/j.ijproman.2011.07.001

Angus, G. Y.; Flett, P. D.; Bowers, J. A. 2005. Developing a value-centred proposal for assessing project success, International Journal of Project Management 23(6): 428-436. https://doi.org/10.1016/j.ijproman.2005.01.008

Arditi, D.; Kale, S.; Tangkar, M. 1997. Innovation in construction equipment and its flow into the construction industry, Journal of Construction Engineering and Management 4: 371-378. https://doi.org/10.1061/(ASCE)07339364(1997)123:4(371)

Aydogan, E. K. 2011. Performance measurement model for Turkish aviation firms using the rough-AHP and TOPSIS methods under fuzzy environment, Expert Systems with Applications 38(4): 3992-3998. https://doi.org/10.1016/j.eswa.2010.09.060

Bassioni, H. A.; Price, A. D.; Hassan, T. M. 2004. Performance measurement in construction, Journal of Management in Engineering 20(2): 42-50.

https://doi.org/10.1061/(ASCE)0742-597X(2004)20:2(42)

Büyüközkan, G.; Çifçi, G. 2012. A novel hybrid MCDM approach based on fuzzy DEMATEL, fuzzy ANP and fuzzy TOPSIS to evaluate green suppliers, Expert Systems with Applications 39(3): 3000-3011.

https://doi.org/10.1016/j.eswa.2011.08.162

Chan, E.; Lee, G. K. 2008. Critical factors for improving social sustainability of urban renewal projects, Social Indicators Research 85(2): 243-256. https://doi.org/10.1007/s11205-007-9089-3

Chang, D. Y. 1992. Extent analysis and synthetic decision, optimization techniques and applications, Optimization Techniques and Applications 1: 352-355.

Chang, D. Y. 1996. Applications of the extent analysis method on fuzzy AHP, European Journal of Operational Research 95(3): 649-655.

https://doi.org/10.1016/0377-2217(95)00300-2 
Cox, R. F.; Issa, R. R.; Ahrens, D. 2003. Management's perception of key performance indicators for construction, Journal of Construction Engineering and Management 129(2): 142-151. https://doi.org/10.1061/(ASCE)07339364(2003)129:2(142)

Da Silva, L.; Ruwanpura, J. Y. 2009. Review of the LEED points obtained by Canadian building projects, Journal of Architectural Engineering 15(2): 38-54. https://doi.org/10.1061/(ASCE)1076-0431(2009)15:2(38)

Dikmen, I.; Talat Birgonul, M.; Ozorhon, B.; Egilmezer Sapci, N. 2010. Using analytic network process to assess business failure risks of construction firms, Engineering, Construction and Architectural Management 17(4): 369386. https://doi.org/10.1108/09699981011056574

Ertuğrul, İ.; Karakaşoğlu, N. 2009. Performance evaluation of Turkish cement firms with fuzzy analytic hierarchy process and TOPSIS methods, Expert Systems with Applications 36(1): 702-715. https://doi.org/10.1016/j.eswa.2007.10.014

Fernández-Sánchez, G.; Rodríguez-López, F. 2010. A methodology to identify sustainability indicators in construction project management - application to infrastructure projects in Spain, Ecological Indicators 10(6): 1193-1201. https://doi.org/10.1016/j.ecolind.2010.04.009

Figge, F.; Hahn, T.; Schaltegger, S.; Wagner, M. 2002. The sustainability balanced scorecard-linking sustainability management to business strategy, Business Strategy and the Environment 11(5): 269-284. https://doi.org/10.1002/bse.339

Golden, B. L.; Harker, P. T.; Wasil, E. E. 1989. The analytic hierarchy process: applications and studies. Berlin: Springer-Verlag. https://doi.org/10.1007/978-3-642-50244-6

Hemphill, L.; Berry, J.; McGreal, S. 2004. An indicator-based approach to measuring sustainable urban regeneration performance: Part 2, empirical evaluation and case-study analysis, Urban Studies 41(4): 757-772. https://doi.org/10.1080/0042098042000194098

Hunt, D. V.; Lombardi, D. R.; Rogers, C. D.; Jefferson, I. 2008. Application of sustainability indicators in decision-making processes for urban regeneration projects, ICE-Engineering Sustainability 161(1): 77-91. https://doi.org/10.1680/ensu.2008.161.1.77

Kaplan, R. S.; Norton, D. P. 1992. The balanced scorecardmeasures that drive performance, Harvard Business Review January-February: 71-79.

Kim, D. Y.; Han, S. H.; Kim, H.; Park, H. 2009. Structuring the prediction model of project performance for international construction projects: A comparative analysis, Expert Systems with Applications 36(2): 1961-1971. https://doi.org/10.1016/j.eswa.2007.12.048

Kwong, C. K.; Bai, H. 2003. Determining the importance weights for the customer requirements in QFD using a fuzzy AHP with an extent analysis approach, Iie Transactions 35(7): 619-626. https://doi.org/10.1080/07408170304355

Labuschagne, C.; Brent, A. C.; Van Erck, R. P. 2005. Assessing the sustainability performances of industries, Journal of Cleaner Production 13(4): 373-385.

https://doi.org/10.1016/j.jclepro.2003.10.007

Langstraat, J. W. 2006. The urban regeneration industry in Leeds: measuring sustainable urban regeneration performance, Earth \& Environment 2(1): 167-210.

Lee, A. H.; Chen, W. C.; Chang, C. J. 2008. A fuzzy AHP and BSC approach for evaluating performance of IT department in the manufacturing industry in Taiwan, Expert Systems with Applications 34(1): 96-107. https://doi.org/10.1016/j.eswa.2006.08.022

Lee, S. H. 2010. Using fuzzy AHP to develop intellectual capital evaluation model for assessing their performance contribution in a university, Expert Systems with Applications 37(7): 4941-4947. https://doi.org/10.1016/j.eswa.2009.12.020
Liu, K. F.; Lai, J. H. 2009. Decision-support for environmental impact assessment: a hybrid approach using fuzzy logic and fuzzy analytic network process, Expert Systems with Applications 36(3): 5119-5136.

https://doi.org/10.1016/j.eswa.2008.06.045

Love, P. E.; Holt, G. D. 2000. Construction business performance measurement: the SPM alternative, Business Process Management Journal 6(5): 408-416. https://doi.org/10.1108/14637150010352417

Luu, T. V.; Kim, S. Y.; Cao, H. L.; Park, Y. M. 2008. Performance measurement of construction firms in developing countries, Construction Management and Economics 26(4): 373-386. https://doi.org/10.1080/01446190801918706

Michael, F. L.; Noor, Z. Z.; Zardari, N. H.; Meza, M. J. F. 2013. Analytical hierarchy process application in urban sustainability indicators prioritization, Resources and Environment 3(A): 1-5.

Mikhailov, L.; Singh, M. G. 2003. Fuzzy analytic network process and its application to the development of decision support systems, IEEE Transactions on Systems, Man, and Cybernetics, Part C: Applications and Reviews 33(1): 3341. https://doi.org/10.1109/TSMCC.2003.809354

OECD. 2009. Sustainable manufacturing and eco-innovation framework, practices and measurement: Synthesis Report [online], [cited 09 November 2015]. Available from Internet: http://www.oecd.org/innovation/inno/43423689.pdf

Parkinson, M. 1989. The Thatcher government's urban policy, Town Planning Review 69(4): 421-446. https://doi.org/10.3828/tpr.60.4.p84822572811r20p

Porter, M. E. 1990. The competitive advantage of nations, Harvard Business Review 68(2): 73-93. https://doi.org/10.1007/978-1-349-11336-1

Powell, C. 2003. The Delphi technique: myths and realities, Journal of Advanced Nursing 41(4): 376-382. https://doi.org/10.1046/j.1365-2648.2003.02537.x

Rivard, H. 2000. A survey on the impact of information technology on the Canadian architecture, engineering and construction industry, Electronic Journal of Information Technology in Construction 5: 37-56.

Saaty, T. L. 1980. The analytic hierarchy process. New York: McGraw-Hill.

Sarshar, M.; Haigh, R.; Amaratunga, D. 2004. Improving project processes: best practice case study, Construction Innovation 4(2): 69-82. https://doi.org/10.1108/14714170410815015

Shen, L. Y.; Ochoa, J. J.; Shah, M. N.; Zhang, X. 2011. The application of urban sustainability indicators - a comparison between various practices, Habitat International 35(1): 17-29. https://doi.org/10.1016/j.habitatint.2010.03.006

Sun, C. C. 2010. A performance evaluation model by integrating fuzzy AHP and fuzzy TOPSIS methods, Expert Systems with Applications 37(12): 7745-7754. https://doi.org/10.1016/j.eswa.2010.04.066

Wang, X.; Huang, J. 2006. The relationships between key stakeholders' project performance and project success: perceptions of Chinese construction supervising engineers, International Journal of Project Management 24(3): 253-260. https://doi.org/10.1016/j.ijproman.2005.11.006

Yang, J.; Shen, G. Q.; Ho, M.; Drew, D. S.; Chan, A. P. 2009. Exploring critical success factors for stakeholder management in construction projects, Journal of Civil Engineering and Management 15(4): 337-348. https://doi.org/10.3846/1392-3730.2009.15.337-348

Yasmin, F.; Kumar, A.; Kumar, A. 2013. Fuzzy theory concept applied in analytic network process, International Journal of Advanced Research in Computer Science and Software Engineering 3(5): 832-837. 
Zeynep IŞIK. She has been working as a faculty member in Civil Engineering Department of Yıldız Technical University since 2010. She obtained her PhD in Construction Management and Engineering from Middle East Technical University, Ankara where she also worked as a research assistant between the years 2004 and 2009. She completed part of her PhD research in Illinois Institute of Technology in Chicago as a Fulbright Research Scholar. She obtained her BSc and MSc in Civil Engineering from Y1ldız Technical University, Istanbul at 2002 and 2004. Her research interest areas are construction management, project management, strategic management, sustainable structures, performance management, risk management, urban regeneration, cost management, building information modelling. Dr. IŞIK has been involved in several national and international research projects as a manager and researcher, written conference and journal articles in the area of construction management.

Hande ALADAG. She is currently a PhD candidate in Construction Management at Y1ldiz Technical University. She obtained her MSc in Construction Management and her BSc in Architecture from Y1ldiz Technical University, Istanbul at years 2010 and 2007. Her research interest areas are construction management, project management, strategic management, sustainable architecture, performance management, risk management, urban regeneration and building information modelling. Ms. ALADAG has been working as a research assistant in Civil Engineering Department of Yıldız Technical University since 2008. Ms. ALADAG has written several conference and journal articles in the area of construction management. 